\title{
Preface: honoring the career of Russell K. Monson
}

\author{
Amy M. Trowbridge ${ }^{1} \cdot$ David J. P. Moore ${ }^{2} \cdot$ Paul C. Stoy $^{3}$ \\ Received: 24 July 2021 / Accepted: 4 October 2021 / Published online: 27 October 2021 \\ (c) The Author(s), under exclusive licence to Springer-Verlag GmbH Germany, part of Springer Nature 2021
}

\section{Introduction}

Music, like science, is a powerful tool. It ignites in us a sense of connection and provides a natural means to create lasting bonds to our surroundings, our experiences, and to each other. Music not only tethers us to people and places, but also elicits a range of emotions through the integration of melodies, harmony, rhythm, and timbre. It is the role of the composer, however, to weave that musical energy together in a coherent way, to take seemingly random notes and "noise" and craft a story - a symphony. The ability to take musical energy and harness that into powerful narratives and soundtracks is a gift; one that continues to transform people long after the song is written. Like a composer, finding order and rhythm in the world around him is something Professor Russell Monson excels at, not only through the music he creates on his burgundy merlot sparkle drum set, but also through his scientific endeavors that have provided clarity and new insights with regards to our understanding of the complex patterns of nature.

As scientists, we are encouraged to find ways to increase the "signal to noise ratio", to diminish that which obscures our ability to understand how systems operate. Russ's scientific intuition and ability to find signals within the complexity that occurs in natural systems is unparalleled. Like a great composer, Russ acknowledges and appreciates variation, and by integrating that into his work has made significant contributions to our ecological and evolutionary understanding of plants and their role in the Earth system. Russ also has the

Communicated by Katherine L. Gross.

Amy M. Trowbridge

amtrowbridge@wisc.edu

1 Department of Entomology, University of Wisconsin, Madison, USA

2 School of Natural Resources and the Environment, University of Arizona, Tucson, USA

3 Department of Biological Systems Engineering, University of Wisconsin, Madison, USA skill (and capacity) to synthesize complex results and ideas into exceptionally clear narratives. This has made his work accessible to cross-disciplinary audiences. A prime example of this can be seen in Russ's recent New Phytologist Trust Keynote seminar on leaf isoprene emissions, a topic he has studied for most of his career. In that keynote address, Russ intuitively coupled molecular insights and principles of evolution to unveil a new theoretical framework for interpreting adaptive plant resource allocation (Monson et al. 2021). Furthermore, Russ's integrative and cross-scale approach to science has inspired the next generation of plant ecologists to work and think without barriers, examples of which are found widely through the scientific literature and, notably, throughout this Special Issue.

This Special Issue Honoring Russell Monson was organized to honor Russ's impressive scientific accomplishments and his far-reaching impact on the scientific community that has significantly advanced the fields of plant physiological and ecosystem ecology. His legacy is certain to continue through the work of his many graduate students and postdoctoral fellows who have gone on to blaze their own trails but are bonded together through a shared appreciation (instilled by Russ) for science, dry German Rieslings, and great jazz. We have included in this Special Issue papers by some of Russ's collaborators that showcase how Russ's research motivated their work-and continues to do so. Russ and his students and collaborators continue to serve as highly regarded experts in their respective fields, which range from the evolution of photosynthesis to the synthesis and function of biogenic volatile organic compounds (BVOCs) to whole-ecosystem exchange of carbon, water, and energy to climate reconstruction from tree rings. The range of topics included in this issue is a testament to Russ's breadth as a scientist and the interdisciplinary perspectives that Russ has traversed and merged. Our goal in compiling this Special Issue was to provide inspiration for all current and future plant and ecosystem scientists eager to weave the stories and melodies of their environments into new syntheses. 
To properly detail all of Russ's honors and accomplishments we would likely find ourselves far beyond Oecologia's allotted word-count so we will have to sacrifice completeness for brevity here. Russ began his career at the University of Colorado at Boulder where he was on the faculty for 30 years and served as the Chair of the Department of Environmental, Population, and Organismic Biology from 2001 to 2004. At CU-Boulder, he mentored $13 \mathrm{PhD}$ students, 22 postdoctoral fellows, and taught (and inspired) innumerable undergraduates and, in 2010, was recognized as a Professor of Distinction. During this time, Russ was also a visiting scholar at some of the most prestigious institutions in Germany, including the University of Bayreuth, the Max Planck Institute in Mainz, and the University of Freiburg. His work in Germany was supported by prestigious fellowships through the Alexander von Humboldt Foundation, The Guggenheim Foundation, and The Fulbright Foundation, respectively. The research conducted with colleagues during these fellowships not only led to key scientific discoveries, but also lifelong friendships and the utmost appreciation for traditional German breakfasts. In 2011, Russ left his position in Boulder to become the Louise Foucar Marshall Professor at the University of Arizona. There he conducted research aimed at understanding tree ecological responses to climate change at both the organismal and macrosystem scale in the world-renowned Laboratory of Tree-Ring Research. While at the University of Arizona, Russ also conducted the groove as the drummer for a Tucson-based Grateful Dead cover band, in which he was an unfunded collaborator. He retired in 2020, with emeritus status and moved to Portland, Oregon, where he continues to be active in scientific research and community organizations.

Russ has also made an indelible mark on the next generation of scientists through his service and outreach efforts. Not only has Russ directly contributed high-impact science throughout his career, but he has also served as an EditorIn-Chief at Oecologia since 2006 and continues to do so, applying his rigorous scientific standards to published work in the journal and elevating its visibility as a leader in ecology. His leadership and vision were also key in establishing and organizing the long-running annual summer Flux Course. This residential summer course brings two dozen early career scientists to the Colorado Rockies each year and more than three hundred scientists can call themselves alumni to date. His contributions to science, students, and society were recognized as he was elected as a fellow of both the American Geophysical Union in 2013 and the Ecological Society of America in 2017. Russ has authored two books, has edited three books, and has published more than 240 peer-reviewed scientific papers. The book he co-authored with Rowan Sage "C4 Plant Biology" (Sage and Monson 1998), has over 500 citations at the time of submitting this piece (September 2021) and his peer-reviewed publications have nearly 33,000 citations in Google Scholar-a clear testament to the impact that he has had on the field of plant physiological and ecosystem ecology.

The papers in this Special Issue only capture part of Russ's influence on plant evolution, plant physiological ecology, ecosystem science, and climate science. That being said, we are indebted to the contributors for their willingness to submit novel results and new syntheses that capture nearly the full range of Russ's scientific interests. We briefly describe how each paper was inspired by Russ's research in topics ranging from the evolution of photosynthesis to BVOC biosynthesis to plant and ecosystem ecology and treering research, all the while noting how these manuscripts follow the rhythm of his career.

\section{Evolution of photosynthetic pathways}

One of Russ's initial research interests was the evolution of C4 photosynthesis (Monson 1999) and crassulacean acid metabolism (CAM) (Monson 1989) including intermediate photosynthetic pathways (Monson and Moore 1989; Schuster and Monson 1990). This led to a long-standing interest in models to describe photosynthesis at the leaf, plant, and ecosystem scale (Monson et al. 1983; Sage and Monson 1999; Monsoon and Baldocchi, 2014). In this issue, Sage (2021) describes Russ's varied and critical contributions to C4 evolution research. Johnson et al. (2021) expound upon this overview by introducing a model that builds off the classic Farquhar-von Caemmerer-Berry (FvCB) model of $\mathrm{C} 3$ photosynthesis to include $\mathrm{C} 3-\mathrm{C} 4$ intermediates and $\mathrm{C} 4$ photosynthesis. Their work poses key questions as to how different photosynthetic pathways optimize beneficial features while minimizing costs. Haworth et al. (2021) provide additional insight into this topic by showing how the evolution of stomatal physiology and morphology are key to understanding how plants evolved to control $\mathrm{CO}_{2}$ uptake into leaves. These questions regarding photosynthetic carbon gain and plant carbon allocation progressed to comprise a central theme of Russ's research: how and why plants allocate carbon resources toward certain functions, especially isoprene and terpenoid biosynthesis.

\section{The evolution and function of isoprene and terpenoid biosynthesis}

Once carbon enters a plant, where does it go? And why have some plants evolved to emit a large portion of that newly assimilated carbon as isoprene (Harley et al. 1999; Sharkey and Monson 2017), others have not, and some have gained and then lost the ability to synthesize isoprene over evolutionary time (Monson et al. 2013)? A paper led by Russ 
(Monson et al. 2021) creates a framework to answer these questions by providing molecular evidence that isoprene serves as a signaling molecule capable of up-regulating defense and stress tolerance pathways. Recognizing that isoprene is a central control point for gene expression and protein abundance moves our understanding beyond its roles of reducing reactive oxygen and altering membrane properties and towards a new interpretation of its function in growth-defense tradeoffs and carbon allocation strategies. Additional empirical evidence for a coupled role of isoprene biosynthesis and protein expression is provided by Ghirardo et al. (2021). This study demonstrates a downregulation of secondary metabolism under heat stress in date palm (Phoenix dactylifera) but upregulation of $P$. dactylifera isoprene synthase (PdIspS), which the authors notably characterize for the first time. Understanding the dynamic interplay between isoprene biosynthesis and protein synthesis under heat and drought stress has major implications for our understanding of how plants have evolved and how they continue to respond to global change.

Understanding the consequences of global climate change has long been a focus of Russ's research. The Mountain West and southwestern U.S., where Russ spent his entire post-PhD career, are experiencing unprecedented warming and drying trends due to anthropogenic global change (Cook et al. 2015). One of the many ways plants alter their function in response to a changing climate is through shifts in the production and efflux of monoterpenes, many of which play critical roles in plant defense against insect herbivory (Litvak and Monson 1998; Trowbridge et al. 2014; Harley et al. 2014; Eller et al. 2016). Trowbridge et al. (2021) summarize findings from a long-term heat and drought experiment on mature pinon pines (Pinus edulis). They show that heat and drought together increase total needle and woody tissue monoterpene concentrations but decrease the concentrations of key monoterpene compounds known to impact bark beetle physiology, with implications for plant-insect interactions. Similarly, Birami et al. (2021) quantify drought-induced biogenic volatile organic compound (BVOC) dynamics in Aleppo pine (P. halepensis) and demonstrate that successive droughts tend to decrease the temperature sensitivity of monoterpene efflux. Furthermore, they show that the dynamics of key BVOC species changed well before tree mortality, suggesting that specific shifts in plant chemistry may indeed be viewed as harbingers of their demise. Pines are certainly not the only genus capable of emitting significant terpene fluxes. Dani et al. (2020) provide an interesting analysis of monoterpene flux from roses that cuts across Russ's research interests in evolution, terpenoid fluxes, and plant phenology. They find that wild roses with more monoterpene flux have longer floral life spans due in part to lower oxidative damage. Russ's research has inspired countless studies to understand how the chemistry of plants and ecosystems respond to global changes, and his leadership in ecosystem and global change science laid out a pathway to do so.

While much of Russ's work has focused on physiological change in aboveground tissues, his contributions to understanding mechanisms driving belowground processes are equally impressive. Much previous research was centered on the assumption that soils were net sources of BVOCs; however, Russ and colleagues demonstrated that soils and plant litter BVOC fluxes are quite dynamic and that soils may serve as sinks under some conditions (Gray et al. 2014). Since then, research has focused on determining the relative contribution of belowground BVOC fluxes to ecosystem BVOC flux. Stoy et al. (2021) provide evidence that soils comprise a trivial amount of total ecosystem flux of some BVOCs but not others. Vapor pressure deficit is a necessary input to simple models of soil and plant BVOC flux, suggesting that models for ecosystem VOC flux could be further improved by integrating more micrometeorological inputs.

\section{Plant and ecosystem ecology}

Russ' long-standing interest in climate change impacts on vegetation led him to establish one of the first long-term eddy covariance research sites at Niwot Ridge, US-NR1, in 1998 (Burns et al. 2016). He pioneered the use of this technique to investigate ecosystem ecology with colleagues in the flux community. His work at Niwot Ridge explored ecosystem carbon and water cycle processes across seasons (Hu et al. 2010; Knowles et al. 2015) and in harsh winter conditions (Monson et al. 2005, 2006; Bowling et al. 2009). These studies advanced our understanding of how soil microbial communities influence forest carbon exchange (Monson et al. 2006) which informed the development of advanced modelling approaches to study surface-atmosphere fluxes (Sacks et al. 2006, 2007), and subsequently pointed to the need to better understand microbial drivers of soil respiratory fluxes (Zobitz et al. 2008; Moore et al. 2013; Trahan et al. 2015). The critical role of soil processes to ecosystem carbon flux is explored by Jung et al. (2021) using the TECO model in a mixed-grass prairie. They demonstrate that changing sensitivity of microbial respiration across multiple years is key for successful model fit. Mauritz and Lipson (2021) note that plant community composition is critical for understanding the temperature sensitivity of soil respiration in a semi-arid shrubland, further emphasizing the importance of plant processes to belowground ecosystem carbon dynamics.

Russ has a longstanding interest in the physiological ecology of plants in desert and semiarid systems (Smith et al. 1997), and several studies in this Special Issue advance our understanding of vegetation responses to water availability. For example, Carroll et al. (2021) find that intense drought 
decreased aboveground net primary productivity in different grasslands more than chronic drought and that wetter systems experienced a greater decrease in belowground net primary productivity under intense drought. In addition, Driscoll et al. (2021) find little evidence that "conservative" water use strategies benefitted fitness of Encelia farinosa (brittlebrush) during dry years nor that "aggressive" water use was universally beneficial during wet years. Goud et al. (2021) note that plant water use strategies are an important mechanism for maintaining biodiversity in the face of fluctuating hydrologic conditions. Extending plant and ecosystem hydrology to the watershed scale, Clute et al. (2020) find that landscape position plays little role in plant hydraulic traits like xylem cavitation, and that whole-tree morphology and physiology is more important for water relations across mountain landscapes. The contribution from Hiltbrunner et al. (2021) extends this focus to alpine environments. They find that tall and short alpine plants do not differ in overall biomass allocation, and tall plants do not rely on their greater belowground $\mathrm{C}$ reserves in rhizomes to support young, unfolding leaves. Studies of plant carbon allocation in the face of environmental stress were a major focus of Russ's research program while at the University of Arizona's Laboratory of Tree-Ring Research.

\section{Tree-ring research}

It has long been known that vegetation response to environmental variability is revealed by tree rings (e.g., Monson et al. 2018) and that a careful study of their anatomy provides critical insight into plant physiological responses to climate. Szejner et al. (2021) assess stable isotopes in tree rings to reveal that trees near the arid range limit herald recent megadroughts in the southwestern U.S. Heilman et al. (2021) use tree rings to find that plant water use efficiency has increased across the savanna-forest ecotone in the Midwestern U.S., but also show that growth has not and is now less sensitive to precipitation variability, especially in trees growing in open canopy microclimates. All these dynamics play out across large regions, and Fang et al. (2021) note that Mediterranean Europe and North Africa have become shrubbier over the satellite record in part because shrubs are more resilient against recent extreme droughts than forests.

\section{Conclusions}

Emerging generations of scientists are the key to understanding how global changes are affecting global ecosystems. They guide all of us to become better stewards of the Earth system. Russ's research and outreach throughout his illustrious career has brought hundreds of international students, postdocs, and scientists to the Colorado Rockies to train and learn, leaving science and mentorship in the field of plant physiological ecology in great hands. To continue Russ's legacy of excellence in plant and ecosystem research, current and future scientists should strive to creatively apply fundamental scientific principles across scales of biological organization. We hope that the papers in this Special Issue will provide new ideas and foster cutting-edge research that can help address the many ecological challenges we face and teach us how to sustainably thrive on an ever-changing planet. And the beat goes on. Thanks for the lessons, Russ.

Acknowledgements We thank Russ Monson for decades of mentorship, ideas, and inspiration and look forward to many more years of scientific leadership. We also thank Dr. Katherine Gross and her editorial assistant, Dr. Tomomi Suwa, for their help in making this Special Issue a reality. Dr. Christine Roscher and Dr. Hermann Heilmeier provided editorial support to Stoy and Trowbridge, and along with multiple referees, ensured that all articles in the Special Issue meet Russ's high standards of scientific quality. Dr. Richard Phillips and Dr. Hank Loescher provided key discussions and ideas. Last, but certainly not least, we thank Jane Monson for making most anything possible.

Author contribution statement AMT, DJPM, and PCS wrote the text.

\section{References}

Birami B, Bamberger I, Ghirardo A, Grote R, Arneth A, GaonaClomán E, Nadal-Sala D, Ruehr NK (2021) Heatwave frequency and seedling death alter stress-specific emissions of volatile organic compounds in Aleppo pine. Oecologia. https://doi.org/ 10.1007/s00442-021-04905-y

Bowling DR, Massman WJ, Schaeffer SM, Burns SP, Monson RK, Williams MW (2009) Biological and physical influences on the carbon isotope content of $\mathrm{CO}_{2}$ in a subalpine forest snowpack, Niwot Ridge, Colorado. Biogeochemistry 95:37-59. https://doi. org/10.1007/s10533-008-9233-4

Burns SP, Maclean GD, Blanken PD, Oncley SP, Semmer SR, Monson RK (2016) The niwot ridge subalpine forest US-NR1 AmeriFlux site-Part 1: data acquisition and site record-keeping. Geosci Instrum Methods Data Syst 5:451-471. https://doi.org/10.5194/ gi-5-451-2016

Carroll CJW, Slette IJ, Griffin-Nolan RJ, Baur LE, Hoffman AM, Denton EM, Gray JE, Post AK, Johnston MK, Yu Q, Collins SL, Luo Y, Smith MD, Knapp AK (2021) Is a drought a drought in grasslands? Productivity responses to different types of drought. Oecologia. https://doi.org/10.1007/s00442-020-04793-8

Clute T, Martin J, Looker N, Hu J (2020) Hydraulic traits of co-existing conifers do not correlate with local hydroclimate condition: a case study in the northern Rocky Mountains, U.S.A. Oecologia. https:// doi.org/10.1007/s00442-020-04772-z

Cook BI, Ault TR, Smerdon JE (2015) Unprecedented 21st century drought risk in the American Southwest and Central Plains. Sci Adv 1(1):e1400082. https://doi.org/10.1126/sciadv.1400082

Dani KGS, Fineschi S, Michelozzi M, Trivellini A, Pollastri S, Loreto F (2020) Diversification of petal monoterpene profiles during floral development and senescence in wild roses: relationships among geraniol content, petal colour, and floral lifespan. Oecologia. https://doi.org/10.1007/s00442-020-04710-z

Driscoll AW, Bitter NQ, Ehleringer JR (2021) Interactions among intrinsic water-use efficiency and climate influence growth and 
flowering in a common desert shrub. Oecologia. https://doi.org/ 10.1007/s00442-020-04825-3

Eller ASD, Young LL, Trowbridge AM, Monson RK (2016) Differential controls by climate and physiology over the emission rates of biogenic volatile organic compounds from mature trees in a semi-arid pine forest. Oecologia 180:345-358. https://doi.org/10. 1007/s00442-015-3474-4

Fang W, Yi C, Chen D et al (2021) Hotter and drier climate made the Mediterranean Europe and Northern Africa region a shrubbier landscape. Oecologia. https://doi.org/10.1007/ s00442-021-05041-3

Ghirardo A, Nosenko T, Kreuzwieser J, Winkler JB, Kruse J, Albert A, Merl-Pham J, Lux T, Ache P, Zimmer I, Alfarraj S, Mayer KFX, Hedrich R, Rennenberg H, Schnitzler JP (2021) Protein expression plasticity contributes to heat and drought tolerance of date palm. Oecologia. https://doi.org/10.1007/s00442-021-04907-w

Goud EM, Prehmus SK, Sparks JP (2021) Is variation in inter-annual precipitation a mechanism for maintaining plant metabolic diversity? Oecologia. https://doi.org/10.1007/s00442-021-05046-y

Gray CM, Monson RK, Fierer N (2014) Biotic and abiotic controls on biogenic volatile organic compound fluxes from a subalpine forest floor. J Geophys Res Biogeosci 119:547-556. https://doi.org/10. 1002/2013JG002575

Harley PC, Monson RK, Lerdau MT (1999) Ecological and evolutionary aspects of isoprene emission from plants. Oecologia 118:109123. https://doi.org/10.1007/s004420050709

Harley P, Eller A, Guenther A, Monson RK (2014) Observations and models of emissions of volatile terpenoid compounds from needles of ponderosa pine trees growing in situ: control by light, temperature and stomatal conductance. Oecologia 176:35-55. https://doi.org/10.1007/s00442-014-3008-5

Haworth M, Marino G, Loreto F, Centritto M (2021) Integrating stomatal physiology and morphology: evolution of stomatal control and development of future crops. Oecologia. https://doi.org/10. 1007/s00442-021-04857-3

Heilman KA, Trouet VM, Belmecheri S, Pederson N, Berke MA, McLachlan JS (2021) Increased water use efficiency leads to decreased precipitation sensitivity of tree growth, but is offset by high temperatures. Oecologia. https://doi.org/10.1007/ s00442-021-04892-0

Hiltbrunner E, Arnaiz J, Körner C (2021) Biomass allocation and seasonal non-structural carbohydrate dynamics do not explain the success of tall forbs in short alpine grassland. Oecologia. https:// doi.org/10.1007/s00442-021-04950-7

Hu J, Moore DJP, Burns SP, Monson RK (2010) Longer growing seasons lead to less carbon sequestration by a subalpine forest. Glob Change Biol 16:771-783. https://doi.org/10.1111/j.1365-2486. 2009.01967.x

Johnson JE, Field CB, Berry JA (2021) The limiting factors and regulatory processes that control the environmental responses of $\mathrm{C} 3$, C3-C4 intermediate, and C4 photosynthesis. Oecologia. https:// doi.org/10.1007/s00442-021-05062-y

Jung CG, Du Z, Hararuk O, Xu X, Liang J, Zhou X, Li D, Jiang L, Luo Y (2021) Long-term measurements in a mixed-grass prairie reveal a change in soil organic carbon recalcitrance and its environmental sensitivity under warming. Oecologia. https://doi.org/ 10.1007/s00442-021-04875-1

Knowles JF, Burns SP, Blanken PD, Monson RK (2015) Fluxes of energy, water, and carbon dioxide from mountain ecosystems at Niwot Ridge, Colorado. Plant Ecol Divers 8:663-676. https://doi. org/10.1080/17550874.2014.904950

Litvak ME, Monson RK (1998) Patterns of induced and constitutive monoterpene production in conifer needles in relation to insect herbivory. Oecologia 114:531-540. https://doi.org/10.1007/s0044 20050477
Mauritz M, Lipson DA (2021) Plant community composition alters moisture and temperature sensitivity of soil respiration in semi-arid shrubland. Oecologia. https://doi.org/10.1007/ s00442-021-04961-4

Monson RK (1999) The origins of C4 genes and evolutionary pattern in the C4 metabolic phenotype. In: Sage RF, Monson RK (eds) C4 Plant Biology. Elsevier, pp 377-410. https://doi.org/10.1016/ B978-012614440-6/50012-4

Monson RK (1989) On the evolutionary pathways resulting in C4 photosynthesis and crassulacean acid metabolism (CAM). Adv Ecol Res 19:57-110. https://doi.org/10.1016/S0065-2504(08)60157-9

Monson RK, Moore B (1989) On the significance of C3-C4 intermediate photosynthesis to the evolution of $\mathrm{C} 4$ photosynthesis. Plant Cell Environ 12:689-699. https://doi.org/10.1111/j.1365-3040. 1989.tb01629.x

Monson RK, Jones RT, Rosenstiel TN, Schnitzler J-P (2013) Why only some plants emit isoprene. Plant Cell Environ 36:503-516. https:// doi.org/10.1111/pce.12015

Monson RK, Lipson DL, Burns SP, Turnipseed AA, Delany AC, Williams MW, Schmidt SK (2006) Winter forest soil respiration controlled by climate and microbial community composition. Nature 439:711-714. https://doi.org/10.1038/nature04555

Monson RK, Littlejohn RO, Williams GJ (1983) Photosynthetic adaptation to temperature in four species from the Colorado shortgrass steppe: A physiological model for coexistence. Oecologia 58:43-15. https://doi.org/10.1007/BF00384540

Monson RK, Sparks JP, Rosenstiel TN, Scott-Denton LE, Huxman TE, Harley PC, Turnipseed AA, Burns SP, Backlund B, Hu J (2005) Climatic influences on net ecosystem $\mathrm{CO}_{2}$ exchange during the transition from wintertime carbon source to springtime carbon sink in a high-elevation, subalpine forest. Oecologia 146:130-147. https://doi.org/10.1007/s00442-005-0169-2

Monson RK, Szejner P, Belmecheri S, Morino KA, Wright WE (2018) Finding the seasons in tree ring stable isotope ratios. Am J Bot 105:819-821. https://doi.org/10.1002/ajb2.1083

Monson RK, Weraduwage SM, Rosenkranz M, Schnitzler J-P, Sharkey TD (2021) Leaf isoprene emission as a trait that mediates the growth-defense tradeoff in the face of climate stress. Oecologia. https://doi.org/10.1007/s00442-020-04813-7

Moore DJP, Trahan NA, Wilkes P, Stephens BB, Elder K, Desai AR, Negron J, Monson RK (2013) Persistent reduced ecosystem respiration after insect disturbance in high elevation forests. Ecol Lett 16:731-737. https://doi.org/10.1111/ele.12097

Sacks WJ, Schimel DS, Monson RK (2007) Coupling between carbon cycling and climate in a high-elevation, subalpine forest: a model-data fusion analysis. Oecologia 151:54-68. https://doi.org/ 10.1007/s00442-006-0565-2

Sacks WJ, Schimel DS, Monson RK, Braswell BH (2006) Model-data synthesis of diurnal and seasonal $\mathrm{CO}_{2}$ fluxes at Niwot Ridge, Colorado. Glob Change Biol 12:240-259. https://doi.org/10.1111/j. 1365-2486.2005.01059.x

Sage RF (2021) Russ Monson and the evolution of C4 photosynthesis. Oecologia. https://doi.org/10.1007/s00442-021-04883-1

Sage RF, Monson RK (1999) C4 Plant Biology. Academic Press, Elsevier. https://doi.org/10.1016/B978-0-12-614440-6.X5000-9

Schuster WS, Monson RK (1990) An examination of the advantages of C3-C4 intermediate photosynthesis in warm environments. Plant Cell Environ 13:903-912. https://doi.org/10.1111/j.13653040.1990.tb01980.x

Sharkey TD, Monson RK (2017) Isoprene research-60 years later, the biology is still enigmatic. Plant Cell Environ 40:1671-1678. https://doi.org/10.1111/pce.12930

Smith SD, Monson RK, Anderson JE (1997) Physiological ecology of North American desert plants. Springer Sci Business Media. https://doi.org/10.1007/978-3-642-59212-6 
Stoy PC, Trowbridge AM, Siqueira MB, Freire LS, Phillips RP, Jacobs L, Wiesner S, Monson RK, Novick KA (2021) Vapor pressure deficit helps explain biogenic volatile organic compound fluxes from the forest floor and canopy of a temperate deciduous forest. Oecologia. https://doi.org/10.1007/s00442-021-04891-1

Szejner P, Belmecheri S, Babst F, Wright WE, Frank DC, Hu J, Monson SK (2021) Stable isotopes of tree rings reveal seasonal-to-decadal patterns during the emergence of a megadrought in the Southwestern US. Oecologia. https://doi.org/10.1007/s00442-021-04916-9

Trahan NA, Dynes EL, Pugh E, Moore DJP, Monson RK (2015) Changes in soil biogeochemistry following disturbance by girdling and mountain pine beetles in subalpine forests. Oecologia 177:981-995. https://doi.org/10.1007/s00442-015-3227-4
Trowbridge AM, Daly RW, Helmig D et al (2014) Herbivory and climate interact serially to control monoterpene emissions from pinyon pine forests. Ecology 95:1591-1603. https://doi.org/10. 1890/13-0989.1

Trowbridge AM, Adams HD, Collins A et al (2021) Hotter droughts alter resource allocation to chemical defenses in piñon pine. Oecologia. https://doi.org/10.1007/s00442-021-05058-8

Zobitz JM, Moore DJP, Sacks WJ, Monson RK, Bowling DR, Schimel DS (2008) Integration of process-based soil respiration models with whole-ecosystem $\mathrm{CO}_{2}$ measurements. Ecosystems 11:250 269. https://doi.org/10.1007/s10021-007-9120-1 